\title{
ASH DEPOSIT CHARACTERISTICS OF BLENDED COAL IN COAL COMBUSTION PROCESS
}

\section{SIFAT ENDAPAN ABU PADUAN BATUBARA DALAM PROSES PEMBAKARAN BATUBARA}

\author{
IKA MONIKA and FAHMI SULISTYOHADI \\ Research \& Development Centre for Mineral and Coal Technology \\ Jalan Jenderal Sudirman 623 Bandung 40211 \\ Ph. (+6222) 6030483, Fax. (+6222) 6003373 \\ e-mail: ika@tekmira.esdm.go.id
}

\begin{abstract}
Coal combustion process often occurs the problems in the reactor which is caused by fouling and slagging. One of the procedures to reduce the risk of fouling and slagging by blending the coal of Pendopo, Palangkaraya, Muara Enim and Samarinda, with the ratio of 25:75, 50:50, and 75:25. The ash deposit tendency is known by analyzing the composition and ash fusion temperature of coal, determining the ash type and calculating of the fouling and slagging. The results showed that the Pendopo and Palangkaraya coal with a ratio of 25:75 and 50:50 were classified as lignite with fouling and the slagging index was classified as a high and medium tendency. While the other blended coal was classified as a low and low-medium tendency.
\end{abstract}

Keywords: coal blending, ratio, slagging index, fouling index

\begin{abstract}
ABSTRAK
Dalam proses pembakaran batubara seringkali terjadi permasalahan di dalam reaktor yang disebabkan penerakan dan pembekuan uap terak. Salah satu cara untuk mengurangi resiko penerakan dan pembekuan uap terak yaitu dengan melakukan paduan batubara dari Pendopo, Palangkaraya, Muara Enim dan Samarinda, dengan nisbah pencampuran 25:75, 50:50, dan 75:25. Potensi pengendapan abu diketahui melalui analisis komposisi dan titik leleh abu batubara, menentukan tipe abu dan menghitung indeks penerakan dan pembukuan uap terak. Hasil penelitian menunjukkan tipe abu paduan batubara Pendopo dan Palangkaraya dengan nisbah pencampuran 25:75 dan 50:50 diklasifikasikan sebagai lignit dengan indeks penerakan dan pembekuan abu terak diklasifikasikan sebagai potensi tinggi dan medium. Sedangkan paduan batubara lainnya dikategorikan berpotensi rendah dan rendah-medium.
\end{abstract}

Kata kunci: paduan batubara, nisbah, indeks penerakan, indeks pembekuan uap terak

\section{INTRODUCTION}

The successful operation of gasification depends on coal characteristics. The suitable of feedstock material is important to inhibit ash-related problems including, agglomeration and slagging in the furnace and fouling on the hot surfaces during coal gasification (Qi et al., 2017). Gasification is an incomplete combustion process, converting a variety of carbon-based feedstock into a clean synthetic gas (syngas), which is primarily a mixture of hydrogen $\left(\mathrm{H}_{2}\right)$ and carbon monoxide (CO) as fuels. The feedstock is partially reacted with oxygen at high temperature and pressurized condition, using less than $30 \%$ of the oxygen required for complete combustion. The syngas produced can be used as a fuel, usually in boilers or gas turbines to generate electricity (Lu and Wang, 2015).

In gasifiers, the carbon in the coal particles is converted into syngas, and the mineral 
matters in the coal are transformed into ash/slag. The majority of the ash is melted and deposited on the walls of the gasifier, forming a liquid slag, which flows out of the bottom of the gasifier and finally solidifies in a water bath (Wang and Massoudi, 2013). The ash problems are mainly rooted in its deposits of slagging and fouling and sintering/agglomeration. It is therefore essential to predict ash-related problems in a thermal environment, particularly when a variety of coal materials are used. These ash deposition problems are influenced by ash fusibility which, in turns, associated with ash composition (Pintana et al., 2014).

Ash slagging and fouling are problem cause the unstable operation of gasification. Ash can be released infused or plastic form. As a result, it will affect on the furnace wall and the other hot wall surfaces. Although ash slagging and fouling occurs in small portions, it can be a big effect in the operation of the boiler. The accumulation of the ash deposits on the furnace wall will affect heat transfer, decrease heat absorption, delay the cooling of flue gas and increase the output temperature of the furnace (Amaliyah and Fachry, 2011).

Several researches have been conducted to study the relationship between the coal ash fusibility and its ash composition. Lolja et al. (2002) found that the oxide composition plays a more important role in fusibility than that of the mineral composition. According to their diverse effects on ash fusibility, the minerals in coal ash are classified as refractory minerals such as quartz, metakaolin, mullite, and rutile, or fluxing minerals gypsum, potash feldspar, fayalite, and almandine (Gupta et al., 2007). Song et al. (2010) reported that the ash fusion temperatures (AFTs) of coal ashes were found to decrease first, reach a minimum, and increase again when the contents of $\mathrm{CaO}, \mathrm{Fe}_{2} \mathrm{O}_{3}$, and $\mathrm{MgO}$ increased, while it decreased continuously with the increase $\mathrm{SiO}_{2}$ to $\mathrm{Al}_{2} \mathrm{O}_{3}$ ratio. Furthermore, $\mathrm{Li}$ et al. (2016) also reported that the too high content of alkali and alkaline metal elements in coal has been considered as the main reason for slagging and fouling.

Blended coal is an effective way to organize and control coal ash fusibility of coal gasification in fired power plants (Shen et al., 2015). Therefore, the blended coal characteristic analysis was conducted to study ash deposition and slag formation behaviors. A better understanding of this study is important to optimize the operation and maintenance of the equipment.

\section{METHODOLOGY}

The samples used in this study are the coal from Palangkaraya, Samarinda, Pendopo and Muara Enim. The study consists of five stages as can be seen in Figure 1.

In the first stage, the coal was pulverized into -60 mesh particle size by determining the size referring to the Standard Method ASTM D 2013-12 (ASTM D2013-12, 2017).

In the second stage, coal characterization consisted of proximate analysis, total sulfur, calorific value, AFT and ash composition. The proximate analysis, total sulfur, and calorific value were used to determine coal classification. The direct analysis included determining water content, ash, volatile material, and fixed carbon.

After coal characterizations, the third stage was blending the coal. In the fourth stage, AFTs and ash composition analyses were conducted before and after blending the coal. AFTs was analyzed to study the temperature of the ash fusion behavior. AFTs was carried out using coal ash as the sample. This analysis refers to ASTM Standard D 1857-17, Standard Test Method for Fusibility of Coal and Coke (ASTM D1857/D1857M-17, 2017). The temperature was observed when the ash form reached the initial phase of deformation, for example: softening, hemispherical, and fluid.

AFTs analysis can be carried out in reducing or oxidizing condition. To prepare the AFTs analysis, dextrin solution is added into coal ash and formed in a mold to make a triangular pyramid (cone) with a height of 0.75 inches and a base pyramid of 0.25 inches. A mixture of dextrin and coal ash was placed in the electric furnace with a temperature of $699-743{ }^{\circ} \mathrm{C}$. The initial deformation temperature (IT) is the initial temperature of formation. It happens when the pyramid peak starts changing to form a second pyramid as shown in Figure 2. 


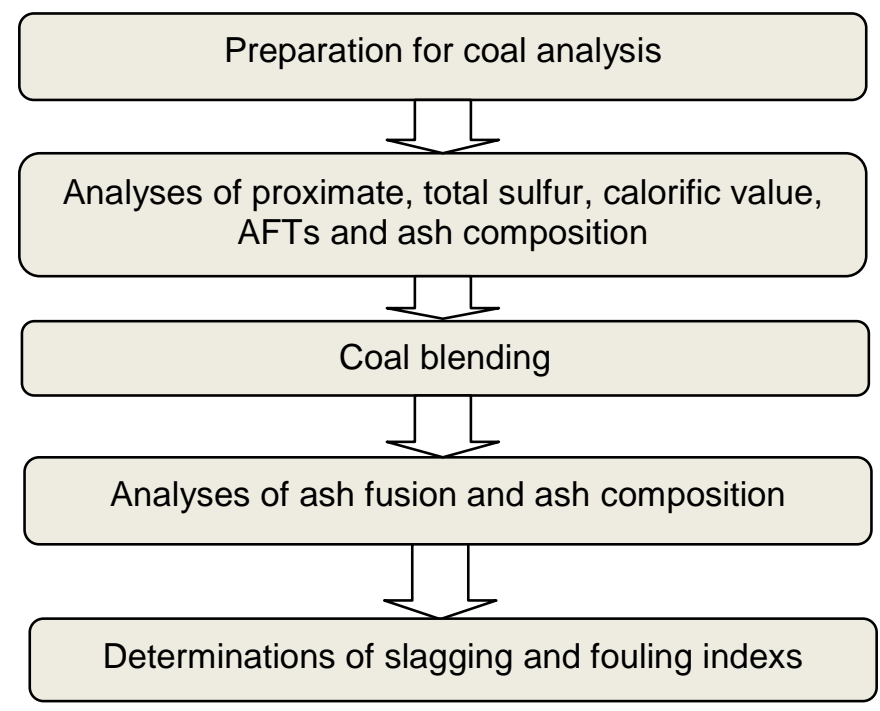

Figure 1. Flow chart of the experiment

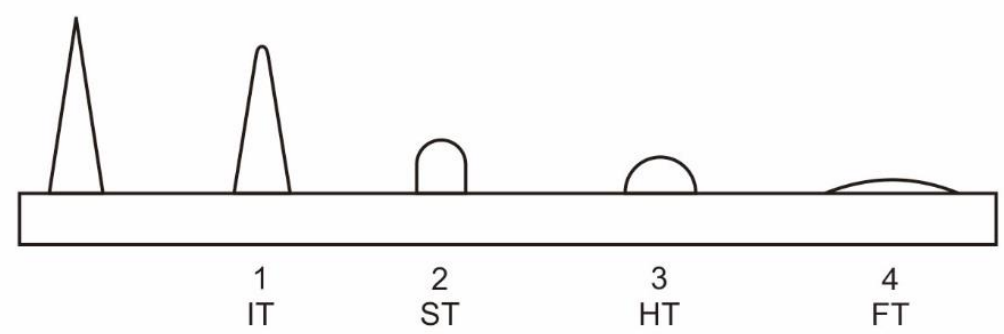

Figure 2. Form of ash fusion (Amaliyah and Fachry, 2011)

Typically, the softening temperature (ST) leads to the fusion temperature. The hemispherical temperature $(\mathrm{HT})$ is temperature which the triangle is formed to a hemispherical lump and the height is equal to half of its width. While fluid temperature (FT) is temperature which ash triangle has been fused with the limit maximum of 0.0625 inches (Amaliyah and Fachry, 2011). Ash composition analysis was conducted by Atomic Absorption Spectrophotometer (AAS). AFTs and ash composition were used to calculate the slagging index and study the potential of coal slagging.
The investigated three blended coal ratios can be seen in Table 1. The total amount of blended coal was $100 \mathrm{gr}$ each.

Table 1. The ratio of blended coal

\begin{tabular}{|c|c|c|}
\hline Blended compositions & $\begin{array}{c}\text { Sample } \\
\text { codes }\end{array}$ & $\begin{array}{l}\text { Blended } \\
\text { ratio }\end{array}$ \\
\hline Pendopo : Palangkaraya & & $25: 75$ \\
\hline Pendopo : Palangkaraya & PP & $50: 50$ \\
\hline Pendopo : Palangkaraya & & $75: 25$ \\
\hline Pendopo : Samarinda & & $25: 75$ \\
\hline Pendopo : Samarinda & PS & $50: 50$ \\
\hline Pendopo : Samarinda & & $75: 25$ \\
\hline Pendopo : Muara Enim & & $25: 75$ \\
\hline Pendopo : Muara Enim & PM & $50: 50$ \\
\hline Pendopo : Muara Enim & & $75: 25$ \\
\hline
\end{tabular}




\section{RESULTS AND DISCUSSION}

\section{Coal Classification}

The four coal samples were primarily pulverized into a particle size of -60 mesh for coal characterizations. Pendopo coal has the highest ash content than that of Palangkaraya, Samarinda and Muara Enim coals. The proximate analysis, total sulfur, and caloric value were characteristics for classifying types of coal.

Coal classification referred to the Annual Book of ASTM Standard D 388-15 (ASTM D388-15, 2017). The basic classification is in accordance with the fixed carbon and gross calorific value calculated to the mineral matter free basis (mmmf). The higher rank coals are classified according to the fixed carbon on a dry basis. The lower rank coals are classified according to the gross calorific value on the moist basis. While the fixed carbon on the dmmf basis is used for classifying coals which have gross calorific values of 14000 $\mathrm{Btu} / \mathrm{bl}$ (mmmf), fixed carbon of $69 \%$ or more on the dry mineral matter free (dmmf) basis, and coals having fixed carbon of $69 \%$ or more on dmmf basis. Coal classification which has gross calorific values less than $14000 \mathrm{Btu} / \mathrm{lb}$ on the mmmf basis and fixed carbon on the dmmf basis is less than $69 \%$, according to the gross calorific value on the $\mathrm{mmmf}$ basis, provided the fixed carbon on the $\mathrm{dmmf}$ basis is less than $69 \%$.
Results of coal characterization analysis (Table 2) were reported in air-dried basis (adb). To convert the adb into the dmmf, it was used Parr Formulas:

$F C(d m m f)=\frac{100(F C-0.15 S)}{(100-(M+1.08 A+0.55 S))}$

$\mathrm{VM}(\mathrm{dmmf})=100-\mathrm{FC}(\mathrm{dmmf})$

Btu $(\mathrm{dmmf})=\frac{100(1.8 \times \mathrm{CV}-50 \mathrm{~S})}{100-(1.08 \mathrm{~A}+0.55 \mathrm{~S})}$

where:

$\mathrm{Btu}=$ gross calorific value, Btu/lb,

$\mathrm{FC}=$ fixed carbon, $\%$,

$\mathrm{VM}=$ volatile matter, $\%$,

$\mathrm{M}=$ moisture, $\%$,

$\mathrm{A}=$ ash, $\%$,

$\mathrm{S}=$ sulfur, $\%$

$\mathrm{CV}=$ caloric value, $\mathrm{cal} / \mathrm{g}$

The results of proximate, sulfur and calorific value analyses from the coal samples were presented in Table 2 and Table 3.

Based on the classification by ASTM (Table 4 ), the coals are grouped into different ranks, namely lignite, sub-bituminous, bituminous, and anthracite. Each rank has the limit value. The result classification of calorific value analysis of the coal samples are presented in Table 5.

Table 2. Result of proximate and sulfur analyses

\begin{tabular}{cccccccc}
\hline \multirow{2}{*}{ Sample names } & \multirow{2}{*}{$\begin{array}{c}\text { Moist. } \\
\text { (\%) adb }\end{array}$} & $\begin{array}{c}\text { Ash } \\
(\%) \text { adb }\end{array}$ & \multicolumn{2}{c}{ Volatile matter } & \multicolumn{2}{c}{ Fixed carbon } & Total sulfur \\
\cline { 4 - 7 } & & & $\begin{array}{c}(\%) \\
\text { adb }\end{array}$ & $\mathrm{dmmf}$ & $\begin{array}{c}(\%) \\
\text { adb }\end{array}$ & $\begin{array}{c}(\%) \\
\text { dmmf }\end{array}$ & \\
\hline Pendopo & 11.90 & 16.67 & 40.26 & 55.50 & 31.17 & 44.50 & 0.26 \\
Palangkaraya & 17.84 & 8.70 & 37.33 & 50.31 & 36.13 & 49.69 & 0.23 \\
Samarinda & 12.33 & 6.47 & 40.10 & 48.99 & 41.10 & 51.01 & 0.43 \\
Muara Enim & 16.06 & 4.79 & 39.43 & 49.54 & 39.72 & 50.46 & 0.24 \\
\hline
\end{tabular}

Table 3. Result of calorific value analysis

\begin{tabular}{cccc}
\hline Sample names & \multicolumn{3}{c}{ Calorific value } \\
\cline { 2 - 4 } & Cal/g (adb) & Btu/lb $(\mathrm{dmmf})$ & Btu/lb $(\mathrm{mmmf})$ \\
\hline Pendopo & 4,287 & 7,717 & 9,412 \\
Palangkaraya & 4,767 & 8,581 & 9,471 \\
Samarinda & 5,548 & 9,986 & 10,740 \\
Muara Enim & 4,969 & 8,944 & 9,432 \\
\hline
\end{tabular}


Table 4. Classification of coals by rank (ASTM D 388-2015)

\begin{tabular}{|c|c|c|c|c|c|c|}
\hline \multirow[b]{2}{*}{ Class/group } & \multicolumn{2}{|c|}{$\begin{array}{l}\text { Fixed carbon limits } \\
\text { (\%) dmmf }\end{array}$} & \multicolumn{2}{|c|}{$\begin{array}{l}\text { Volatile matter limits } \\
\qquad(\%) \text { dmmf }\end{array}$} & \multicolumn{2}{|c|}{$\begin{array}{c}\text { Gross calorificvalue } \\
\text { (Btu/lb) mmmf }\end{array}$} \\
\hline & $\begin{array}{c}\text { Equal or } \\
\text { greater } \\
\text { than }\end{array}$ & $\begin{array}{l}\text { Less } \\
\text { than }\end{array}$ & $\begin{array}{c}\text { Greater } \\
\text { than }\end{array}$ & $\begin{array}{l}\text { Equal or } \\
\text { less than }\end{array}$ & $\begin{array}{c}\text { Equal or } \\
\text { greater } \\
\text { than }\end{array}$ & $\begin{array}{l}\text { Less } \\
\text { than }\end{array}$ \\
\hline \multicolumn{7}{|l|}{ I. Anthracitic } \\
\hline 1. Metaanthracite & 98 & & & 2 & & \\
\hline 2. Anthracite & 92 & 98 & 2 & 8 & & \\
\hline 3. Semianthracite & 86 & 92 & 8 & 14 & & \\
\hline \multicolumn{7}{|l|}{ II. Bituminous } \\
\hline 1. Low volatile & 78 & 86 & 14 & 22 & & \\
\hline 2. Medium volatile & 69 & 78 & 22 & 31 & & \\
\hline 3. High volatile $A$ & & 69 & 31 & & 14,000 & \\
\hline 4. High volatile $B$ & & & & & 13,000 & 14,000 \\
\hline 5. High volatile $\mathrm{C}$ & & & & & 11,500 & 13,000 \\
\hline \multicolumn{7}{|l|}{ III. Sub-bituminous } \\
\hline 1. Sub-bituminous $A$ & & & & & 10,500 & 11,500 \\
\hline 2. Sub-bituminous B & & & & & 9,500 & 10,500 \\
\hline 3. Sub-bituminous $\mathrm{C}$ & & & & & 8,300 & 9,500 \\
\hline \multicolumn{7}{|l|}{ IV. Lignitic } \\
\hline 1. Lignite $A$ & & & & & 6,300 & 8,300 \\
\hline 2. Lignite $B$ & & & & & $<$ & 6,300 \\
\hline
\end{tabular}

Table 5. Coal sample classifications

\begin{tabular}{cc}
\hline Sample names & Classifications \\
\hline Pendopo & Sub-bituminous C \\
Palangkaraya & Sub-bituminous C \\
Samarinda & Sub-bituminous A \\
Muara Enim & Sub-bituminous C \\
\hline
\end{tabular}

\section{AFTs and ash compositions analyses}

Coal gasification has four main processes, namely drying, pyrolysis, oxidation, and reduction. The purpose of the drying stage is to remove the moist content, while the pyrolysis stage will decompose the coal from its charcoal, tar, and gas. The oxidation stage is pyrolysis gas combustion, which is part of charcoal is oxidized into carbon dioxide and others will be in reduction condition. The charcoal reduction process used to steam and carbon dioxide to produce hydrogen and carbon monoxide. Usually, the reduction process occurs at the temperature of $800-1,000{ }^{\circ} \mathrm{C}$, but the reduction temperature occasionally happens at more than $1,000{ }^{\circ} \mathrm{C}$. Therefore, the AFTs analysis was carried out in a reduction condition by considering the occurrence of gasification process under the same conditions. The AFTs are determined in order to provide an indication of how the mineral matter in the coal may behave in the furnace The fusion behavior of the coal ashes is based on the measurement of three major temperatures of IT, HT and FT. By having slag characteristics information, the research can be investigated further by predicting slagging trends. The result of AFTs analysis and ash composition are presented in Table 6 while coal ash composition is presented in Table 7.

Tables 6 shows that the Pendopo coal has the highest AFTs value, however, Muara Enim coal has the lowest AFTs. The low temperature of ash fusion indicates the possibility of slagging problems. The observations are mostly made by considering the IT because most of the melting point takes place in this temperature range. The IT is used to determine the predictive indices for slagging, fouling, and abrasion tendency during combustion practices. 
Table 6. AFTs analysis in the reduction atmosphere

\begin{tabular}{lcccc}
\hline \multirow{2}{*}{ Sample names } & \multicolumn{4}{c}{ temperature changes of coal ash fusion } \\
\cline { 2 - 5 } & $\mathrm{IT}\left({ }^{\circ} \mathrm{C}\right)$ & $\mathrm{ST}\left({ }^{\circ} \mathrm{C}\right)$ & $\mathrm{HT}\left({ }^{\circ} \mathrm{C}\right)$ & $\mathrm{FT}\left({ }^{\circ} \mathrm{C}\right)$ \\
\hline Pendopo & 1,379 & 1,468 & $>1,500$ & $>1,500$ \\
Palangkaraya & 1,262 & 1,263 & 1,299 & 1,342 \\
Samarinda & 1,245 & 1,254 & 1,302 & 1,340 \\
Muara Enim & 1,213 & 1,238 & 1,254 & 1,271 \\
\hline
\end{tabular}

Table 7. Ash composition analysis

\begin{tabular}{lrrrrrrrr}
\hline \multicolumn{1}{c}{ Sample names } & \multicolumn{1}{c}{$\begin{array}{c}\mathrm{MaO} \\
(\%)\end{array}$} & $\begin{array}{c}\mathrm{MgO} \\
(\%)\end{array}$ & $\begin{array}{c}\mathrm{Fe}_{2} \mathrm{O}_{3} \\
(\%)\end{array}$ & $\begin{array}{c}\mathrm{Na}_{2} \mathrm{O} \\
(\%)\end{array}$ & $\begin{array}{c}\mathrm{K}_{2} \mathrm{O} \\
(\%)\end{array}$ & $\begin{array}{c}\mathrm{Al}_{2} \mathrm{O}_{3} \\
(\%)\end{array}$ & $\begin{array}{c}\mathrm{SiO}_{2} \\
(\%)\end{array}$ & $\begin{array}{c}\mathrm{TiO}_{2} \\
(\%)\end{array}$ \\
\hline Pendopo & 3.58 & 0.94 & 10.44 & 0.24 & 0.22 & 32.58 & 44.10 & 1.64 \\
Palangkaraya & 16.16 & 2.99 & 7.22 & 0.27 & 0.36 & 24.99 & 36.90 & 1.61 \\
Samarinda & 7.60 & 2.17 & 8.10 & 0.88 & 0.32 & 23.93 & 45.95 & 1.18 \\
Muara Enim & 21.11 & 8.88 & 28.24 & 3.56 & 0.37 & 1.85 & 18.05 & 0.25 \\
\hline
\end{tabular}

The main constituents of coal ash are silica, alumina and iron oxides with a small percentage of other oxides such as $\mathrm{CaO}$, $\mathrm{MgO}$, and other alkalis. The ash fusibility is reported as a function of these major oxides present in coal ash. The characteristics of coal ash fusibility are difficult to determine precisely because many of the coal ash components do not have a sharp melting point like a pure compound (Sharma et al., 2014). Alkalis oxide, $\mathrm{CaO}, \mathrm{MgO}, \mathrm{K}_{2} \mathrm{O}$, and $\mathrm{Na}_{2} \mathrm{O}$ influence of ash fusibility, especially $\mathrm{Na}_{2} \mathrm{O}$ which shows the occurrence of the slagging and fouling propensities. The fluid form of an alkaline element will be evaporated on the combustion temperature and can be reacted with the sulfur and other ash elements to form a bond. This condition causes the occurrence of slagging and fouling areas (Amaliyah and Fachry, 2011). The result of the ash composition analysis will be used to determine of slagging and fouling indices.

Table 7 shows an increase in the content of $\mathrm{Fe}_{2} \mathrm{O}_{3}$ and the ratio of $\mathrm{SiO}_{2} / \mathrm{Al}_{2} \mathrm{O}_{3}$ except for the Pendopo coal which has a greater content of $\mathrm{Fe}_{2} \mathrm{O}_{3}$ than Palangkaraya and Muara Enim coal. Increasing the content of $\mathrm{Fe}_{2} \mathrm{O}_{3}$ and the ratio of $\mathrm{SiO}_{2} / \mathrm{Al}_{2} \mathrm{O}_{3}$ causes degradation of AFTs.

\section{Slagging index classification}

Coal ash characteristics of bituminous and lignite are very significantly. The first step for calculating of the slagging and fouling index by determining coal ash types (Amaliyah and Fachry, 2011). Ash is classified as bituminous, if:
$\mathrm{Fe}_{2} \mathrm{O}_{3}>\mathrm{CaO}+\mathrm{MgO}$

Ash is classified as lignite ash, if:

$\mathrm{Fe}_{2} \mathrm{O}_{3}<\mathrm{CaO}+\mathrm{MgO}$

Table 8 shows that the ash Pendopo coal was classified as a bituminous, while the Palangkaraya, Samarinda and Muara Enim coals were classified as lignite.

The slagging index $\left(R_{s}\right)$ of solid fuel has been taken as a measure of the slagging propensity of the ash (Russell, Wigley and Williamson, 2002). The ash content is a good indicator of the problematic nature of coal. The propensity of ash deposition may be evaluated in terms of base-to-acid (B/A) ratio. The $B / A$ ratio is an indication of the fusion characteristics and the slagging tendency of coal ash and metalcontaining ash to combine in the combustion process to produce low melting salts (Pintana et al., 2014).

The slagging index classification of bituminous ash was calculated using equation (1), while the slagging index of lignite ash by equation (2) (Amaliyah and Fachry, 2011).

$R_{s}=\frac{B}{A} \times S$

where;

$\mathrm{B}=\mathrm{CaO}+\mathrm{MgO}+\mathrm{Fe}_{2} \mathrm{O}_{3}+\mathrm{Na}_{2} \mathrm{O}+\mathrm{K}_{2} \mathrm{O}=$ base compound, \%

$\mathrm{A}=\mathrm{SiO}_{2}+\mathrm{Al}_{2} \mathrm{O}_{3}+\mathrm{TiO}_{2}=$ acid compound, $\%$

$\mathrm{S}=\mathrm{wt} \%$ of sulfur content in $\mathrm{adb}$ 
Table 8. Ash coal classification

\begin{tabular}{lcccc}
\hline Sample names & $\begin{array}{c}\mathrm{Fe}_{2} \mathrm{O}_{3} \\
(\%)\end{array}$ & & $\begin{array}{c}\mathrm{CaO}+\mathrm{MgO} \\
(\%)\end{array}$ & Ash classification \\
\hline Pendopo & 10.44 & $>$ & 4.52 & bituminous \\
Palangkaraya & 7.22 & $<$ & 19.15 & lignite \\
Samarinda & 8.10 & $<$ & 10.59 & lignite \\
Muara Enim & 28.24 & $<$ & 29.99 & lignite \\
\hline
\end{tabular}

The calculation of slagging index $\left(\mathrm{R}_{\mathrm{s}}{ }^{*}\right)$ for Palangkaraya, Samarinda, and Muara Enim coals (as the lignite ash) depends on the temperature of ash fusion formation. The slagging indices are averages of $(\mathrm{HT})$ and (IT) formations.

$$
\mathrm{R}_{\mathrm{s}}^{*}=\frac{(\operatorname{Max~HT})+4(\operatorname{Min} \mathrm{TT})}{5}
$$

where;

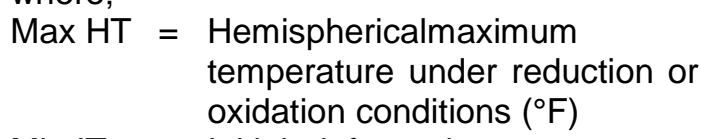

Min IT = Initial deformation temperature under reduction or oxidation conditions $\left({ }^{\circ} \mathrm{F}\right)$

Table 9 shows the Pendopo coal base and the acidic ratio is about 0.05 . The calculated value of 0.05 indicates that the tendency a slagging of ash bituminous classification was low. The results of slagging index calculation of lignite ash in Table 10 indicate that the Palangkaraya and Samarinda coals were classified as a medium slagging tendency, while Muara Enim coal was classified as a high slagging tendency. Besides that, the presence of high iron oxide content amount of $28.24 \%$ in Muara Enim coal ash leads to slagging in radiative heat transfer section in the boiler (Vijay, Lawrence and Arthanareeswaran, 2017).

\section{Fouling Index Classification}

Fouling refers to the dry deposition of ash particles or condensation of volatile inorganic components on heat transfer surfaces. The fouling index $(R f)$ of solid fuel is a measure of the fouling propensity of the ash (Pintana et al., 2014).

The calculation of the fouling index $\left(R_{f}\right)$ of bituminous ash (Pendopo coal) was obtained by sodium and potassium contents and base to the acid ratio (Eq. 3).

$\mathrm{R}_{\mathrm{f}}=\frac{\mathrm{B}}{\mathrm{A}} \times \mathrm{Na}_{2} \mathrm{O}+\mathrm{K}_{2} \mathrm{O}$

Where;

$$
\begin{aligned}
\mathrm{B}= & \mathrm{CaO}+\mathrm{MgO}+\mathrm{Fe}_{2} \mathrm{O}_{3}+\mathrm{Na}_{2} \mathrm{O}+\mathrm{K}_{2} \mathrm{O} \\
& =\text { base compound } \% \\
\mathrm{~A}= & \mathrm{SiO}_{2}+\mathrm{Al}_{2} \mathrm{O}_{3}+\mathrm{TiO}_{2}=\text { acid } \\
& \text { compound } \% \\
\mathrm{Na}_{2} \mathrm{O}= & \text { wt } \% \text { of sodium } \\
\mathrm{K}_{2} \mathrm{O}= & \text { wt } \% \text { of potassium }
\end{aligned}
$$

\begin{tabular}{|c|c|c|c|c|c|c|c|}
\hline \multirow{3}{*}{ Sample names } & \multicolumn{2}{|c|}{$\mathrm{HT}$} & \multicolumn{2}{|c|}{ IT } & \multirow{3}{*}{$\mathrm{R}_{\mathrm{s}}^{*}$} & \multirow{2}{*}{ Slagging index $\left(\mathrm{Rs}^{*}\right)$} & \multirow{2}{*}{ Classfication } \\
\hline & $\left({ }^{\circ} \mathrm{C}\right)$ & $\left(^{\circ} \mathrm{F}\right)$ & $\left({ }^{\circ} \mathrm{C}\right)$ & $\left({ }^{\circ} \mathrm{F}\right)$ & & & \\
\hline & (c) & $(r)$ & (c) & (F) & & $2.450<\mathrm{Rs}^{*}$ & low \\
\hline Palangkaraya & 1,299 & 2,370 & 1,262 & 2,303 & 2,316 & $2.250<\mathrm{Rs}^{*}<2.450$ & medium \\
\hline Samarinda & 1,302 & 2,375 & 1,245 & 2,273 & 2,293 & $2.100<\mathrm{Rs}^{*}<2.250$ & high \\
\hline Muara Enim & 1,254 & 2,289 & 1,213 & 2,215 & 2,230 & $\mathrm{Rs}^{*}<2.100$ & Very high \\
\hline
\end{tabular}

Table 9. Slagging index classification of bituminous ash

\begin{tabular}{ccccccc}
\hline $\begin{array}{c}\text { Sample } \\
\text { name }\end{array}$ & $\begin{array}{c}\text { Acid } \\
\text { compound } \\
(\%)\end{array}$ & $\begin{array}{c}\text { Base } \\
\text { compound } \\
(\%)\end{array}$ & $\begin{array}{c}\text { Sulfur } \\
\text { content }( \\
\% \mathrm{adb})\end{array}$ & $\begin{array}{c}\text { Slagging } \\
\text { index }\left(\mathrm{R}_{\mathrm{s}}\right)\end{array}$ & $\begin{array}{c}\text { Slagging } \\
\text { index }\left(\mathrm{R}_{\mathrm{s}}\right)\end{array}$ & Classification \\
\hline & & & & & $\begin{array}{c}\mathrm{R}_{\mathrm{s}}<0.6 \\
0.6<2.0\end{array}$ & $\begin{array}{c}\text { Low } \\
\text { Medium }\end{array}$ \\
Pendopo & 78.32 & 15.42 & 0.26 & 0.05 & $\begin{array}{c}0.0<\mathrm{R}_{\mathrm{s}}<2.6 \\
2.6<\mathrm{R}_{\mathrm{s}}\end{array}$ & $\begin{array}{c}\text { Medium } \\
\text { Medium }\end{array}$ \\
\hline
\end{tabular}

Table 10. Slagging index classification of lignite ash 
Results of the fouling index calculation for Pendopo coal was 0.27 . Refers to Table 11, this value was between 0.2 and 0.5 and it was categorized as a medium occurrence of fouling propensity.

Table 11. Fouling index classification of bituminous ash

\begin{tabular}{cc}
\hline Fouling index $\left(\mathrm{R}_{\mathrm{f}}\right)$ & Classification \\
\hline $\mathrm{R}_{\mathrm{r}}<0.2$ & Low \\
$0.2<\mathrm{R}_{\mathrm{R}}<0.5$ & Medium \\
$0.5<\mathrm{R}_{\mathrm{k}}<1.0$ & High \\
$1.0<\mathrm{R}_{f}$ & Highest \\
\hline
\end{tabular}

Fouling index classification of lignite ash was based on the total amount of $\mathrm{CaO}, \mathrm{MgO}$ and $\mathrm{Fe}_{2} \mathrm{O}_{3}$ and sodium contents in coal ash. Palangkaraya coal has a total amount of $\mathrm{CaO}, \mathrm{MgO}$ and $\mathrm{Fe}_{2} \mathrm{O}_{3}$ is $26.37 \%$, more than $20 \%$ (Table 13), therefore the fouling index of Palangkaraya coal was classified as a lowmedium, with a sodium content of $0.27 \%$ (Table 7). The Samarinda coal has a total amount of $\mathrm{CaO}, \mathrm{MgO}$, and $\mathrm{Fe}_{2} \mathrm{O}_{3}$ is $17.87 \%$, less than $20 \%$, however, the sodium content in the coal ash is $0.88 \%$. Based on those numbers, then the Samarinda coal was classified as a low medium one. The Muara Enim coal has a total amount of $\mathrm{CaO}, \mathrm{MgO}$ and $\mathrm{Fe}_{2} \mathrm{O}_{3}$ of $58.23 \%$, more than $20 \%$, with the sodium content of $3.56 \%$, then the fouling tendency of Muara Enim coal was classified as a high occurrence fouling. Table 13 presented the fouling propensity classification of lignite ash.

\section{Coal blending Analysis}

After slagging and fouling propensities of each coal were classified by slagging and fouling index determinations, the next step was analyzing the blended coal. Pendopo coal has a low slagging tendency, therefore it was used as the main material for blending to the other coals. This research was conducted to study the effects of blended coal on the decrease of the slagging and fouling propensities. Results of blended coal analysis can be seen in Table 14 and 15.

Results in Table 15 indicated that the ash fusion temperatures of the blended PP coal initially decreased and then increased with the increase of blended ratio. The increased temperature is in line with the raising amount of Pendopo coal. When these results were compared with the fusion temperature of Palangkaraya coal, blended PP coal with a ratio of $75: 25$ caused the increase of fusion temperature.

The blended PS coal showed that the ratio of $25: 75$, fusion temperature decreased to $1,209{ }^{\circ} \mathrm{C}$. It was less than the IT of the Samarinda coal that was in $1,245^{\circ} \mathrm{C}$. $\mathrm{Fe}_{2} \mathrm{O}_{3}$ content and $\mathrm{SiO}_{2} / \mathrm{Al}_{2} \mathrm{O}_{3}$ ratio of the blended PS coal was $11.67 \%$ and 1.37 more than the blended PS coal with the ratio of 50:50 and 75:25. The increase of $\mathrm{Fe}_{2} \mathrm{O}_{3}$ content and $\mathrm{SiO}_{2} / \mathrm{Al}_{2} \mathrm{O}_{3}$ ratio can be caused by a decrease of AFTs. The data also indicated that the amount of Pendopo coal was bigger likewise the ash fusion temperature.

The blended PM coal shows the temperature of $25: 75$ and 50:50 were 1,062 and $1,183{ }^{\circ} \mathrm{C}$ or less than AFTs of Muara Enim coal. The blended PM coal with a ratio of 25:75 and 50:50 have a high $\mathrm{Fe}_{2} \mathrm{O}_{3}$ content of $17.94 \%$ and $14.70 \%$ each. The low temperature of ash fusion indicates the possibility of slagging problems.

Data in Table 16 showed the coal ash type blended coals of PP, PS, and PM. The coal ash type of Palangkaraya before being blended with Pendopo in the form of lignite, the changes occurred into bituminous with the ratio of 75:25. The type of ash coal from Samarinda and Muara Enim coals become bituminous on the ratio of $25: 75,50: 50$ and 75:25.

Table 12. Fouling index classification of lignite ash

\begin{tabular}{cccc}
\hline \multicolumn{2}{c}{$\begin{array}{c}\text { If } \mathrm{CaO}+\mathrm{MgO}+\mathrm{Fe}_{2} \mathrm{O}_{3}>20 \% \\
\text { weight of ash content }\end{array}$} & \multicolumn{2}{c}{$\begin{array}{c}\text { If } \mathrm{CaO}+\mathrm{MgO}+\mathrm{Fe}_{2} \mathrm{O}_{3}<20 \% \\
\text { weight of ash content }\end{array}$} \\
\hline Fouling index $\left(\mathrm{R}_{\mathrm{f}}\right)$ & Classification & Fouling index $\left(\mathrm{R}_{\mathrm{f}}\right)$ & Classification \\
\hline $\mathrm{Na}_{2} \mathrm{O}<3$ & Low-medium & $\mathrm{Na}_{2} \mathrm{O}<1.2$ & Low-medium \\
$3<\mathrm{Na}_{2} \mathrm{O}<6$ & High & $1.2<\mathrm{Na}_{2} \mathrm{O}<3$ & High \\
$\mathrm{Na}_{2} \mathrm{O}>6$ & Highest & $\mathrm{Na}_{2} \mathrm{O}>3$ & Highest \\
\hline
\end{tabular}


Table 13. Fouling classification of lignite ash samples

\begin{tabular}{lccccc}
\hline \multicolumn{1}{c}{ Sample names } & $\mathrm{CaO}(\%)$ & $\mathrm{MgO}(\%)$ & $\begin{array}{c}\mathrm{Fe}_{2} \mathrm{O}_{3} \\
(\%)\end{array}$ & $\begin{array}{c}\text { Total amount } \\
(\%)\end{array}$ & Classification \\
\hline Palangkaraya & 16.16 & 2.99 & 7.22 & 26.37 & Low-medium \\
Samarinda & 7.60 & 2.17 & 8.10 & 17.87 & Low-medium \\
Muara Enim & 21.11 & 8.88 & 28.24 & 58.23 & High \\
\hline
\end{tabular}

Table 14. Ash composition of blended coal

\begin{tabular}{cccccccccc}
\hline $\begin{array}{c}\text { Sample } \\
\text { codes }\end{array}$ & $\begin{array}{c}\text { Blended } \\
\text { coal ratio }\end{array}$ & $\begin{array}{c}\mathrm{CaO} \\
(\%)\end{array}$ & $\begin{array}{c}\mathrm{MgO} \\
(\%)\end{array}$ & $\begin{array}{c}\mathrm{Fe}_{2} \mathrm{O}_{3} \\
(\%)\end{array}$ & $\begin{array}{c}\mathrm{Na}_{2} \mathrm{O} \\
(\%)\end{array}$ & $\begin{array}{c}\mathrm{K}_{2} \mathrm{O} \\
(\%)\end{array}$ & $\begin{array}{c}\mathrm{Al}_{2} \mathrm{O}_{3} \\
(\%)\end{array}$ & $\begin{array}{c}\mathrm{SiO}_{2}(\%) \\
\mathrm{TiO}_{2} \\
(\%)\end{array}$ \\
\hline \multirow{3}{*}{$\mathrm{PP}$} & $25: 75$ & 15.84 & 3.29 & 10.18 & 0.40 & 0.24 & 26.90 & 32.73 & 1.28 \\
& $50: 50$ & 10.20 & 2.23 & 10.79 & 0.31 & 0.19 & 31.20 & 37.4 & 1.35 \\
& $75: 25$ & 6.31 & 1.53 & 10.88 & 0.30 & 0.23 & 33.40 & 41.20 & 1.38 \\
\hline \multirow{3}{*}{$\mathrm{PS}$} & $25: 75$ & 7.46 & 2.27 & 11.67 & 0.57 & 0.31 & 27.76 & 38.00 & 1.20 \\
& $50: 50$ & 5.22 & 1.63 & 11.15 & 0.55 & 0.27 & 30.90 & 41.40 & 1.28 \\
& $75: 25$ & 4.35 & 1.21 & 10.97 & 0.19 & $0 . .22$ & 32.30 & 43.00 & 1.41 \\
\hline \multirow{3}{*}{$\mathrm{PM}$} & $25: 75$ & 10.63 & 4.52 & 17.94 & 1.36 & 0.34 & 16.98 & 38.50 & 0.90 \\
& $50: 50$ & 7.28 & 2.67 & 14.70 & 0.70 & 0.25 & 25.20 & 41.40 & 1.07 \\
& $75: 25$ & 5.04 & 1.65 & 12.42 & 0.62 & 0.23 & 29.33 & 43.10 & 1.33 \\
\hline
\end{tabular}

Table 15. AFTs analysis of blended coal in reduction condition

\begin{tabular}{cccccc}
\hline \multirow{2}{*}{ Sample code } & Blended & \multicolumn{4}{c}{ Change temperatures of coal ash form $\left({ }^{\circ} \mathrm{C}\right)$} \\
\cline { 3 - 6 } & coal ratio & IT & HT & FT & ST \\
\hline \multirow{2}{*}{ PP } & $25: 75$ & 1,208 & 1,233 & 1,284 & 1,314 \\
& $50: 50$ & 1,274 & 1,294 & 1,340 & 1,366 \\
& $75: 25$ & 1,313 & 1,382 & 1,421 & 1,443 \\
\hline \multirow{2}{*}{ PS } & $25: 75$ & 1,209 & 1,242 & 1,249 & 1,274 \\
& $50: 50$ & 1,276 & 1,357 & 1,391 & 1,432 \\
& $75: 25$ & 1,355 & 1,411 & 1,474 & $>1,500$ \\
\hline \multirow{2}{*}{ PM } & $25: 75$ & 1,062 & 1,107 & 1,116 & 1,136 \\
& $50: 50$ & 1,183 & 1,211 & 1,231 & 1,236 \\
& $75: 25$ & 1,315 & 1,247 & 1,381 & 1,431 \\
\hline
\end{tabular}

Table 16. Coal ash type of blended coals

\begin{tabular}{cccccc}
\hline Sample codes & Ratio & $\mathrm{CaO}+\mathrm{MgO}(\%)$ & & $\mathrm{Fe}_{2} \mathrm{O}_{3}(\%)$ & Ash type classification \\
\hline \multirow{2}{*}{ PP } & $25: 75$ & 19.13 & $>$ & 10.18 & Lignit \\
& $50: 50$ & 12.43 & $>$ & 10.79 & Lignit \\
& $75: 25$ & 7.84 & $<$ & 10.88 & Bituminous \\
\hline \multirow{2}{*}{ PS } & $25: 75$ & 9.73 & $<$ & 11.67 & Bituminous \\
& $50: 50$ & 6.85 & $<$ & 11.15 & Bituminous \\
& $75: 25$ & 5.56 & $<$ & 10.97 & Bituminous \\
\hline \multirow{2}{*}{ PM } & $25: 75$ & 15.15 & $<$ & 17.94 & Bituminous \\
& $50: 50$ & 9.95 & $<$ & 14.70 & Bituminous \\
& $75: 25$ & 6.69 & $<$ & 12.42 & Bituminous \\
\hline
\end{tabular}

\section{Slagging Tendency of Blended Coal}

After data coal ash type each was known, the next step was the determination of the slagging classification of the blended coal. The first stage was determined by the coal ash type. The blended PP coal on the ratio of 25:75 and 50:50 were classified as lignite (Table 16). The second stage, the slagging classification using AFTs analysis. Data in Table 17 shows that blended coal of PP on the ratio of 25:75 was categorized as a high slagging tendency. While the ratio of 50:50 was categorized as a medium tendency. 
The determination of slagging tendency of bituminous ash was based on base to acid ratio of the ash compositions and then multiplied to the sulfur content.

The slagging index of all blended coals was obtained less than 0.6. This value was categorized as a low slagging tendency.

\section{Fouling Tendency of Blended Coal}

The calculation of the fouling index $\left(\mathrm{R}_{\mathrm{f}}\right)$ of bituminous ash type was obtained through the base to acid ratio and sodium and potassium contents (Eq. 3).
Referring to Table 19, the fouling index of PP coal at the ratio of 75:25 was obtained 0.13 and categorized as low fouling tendency (according to Table 11). While fouling index of the blended PS and PM coals were obtained in the value of 0.2-0.4 and classified as a medium fouling tendency, while PM coal at the ratio of 25:75 was obtained 1.05 and classified as a high fouling tendency.

The fouling tendency classification of lignite coal ash is shown in Table 20. Refer to Table 12, the blended ratio of PP coal at 25:75 and 50:50 were categorized as lowmedium fouling tendency.

Table 17. The slagging tendency of blended coal (as lignite)

\begin{tabular}{|c|c|c|c|c|c|c|c|}
\hline \multirow[b]{2}{*}{ Sample codes } & \multirow[b]{2}{*}{ Ratio } & \multicolumn{2}{|c|}{$\mathrm{HT}$} & \multicolumn{2}{|c|}{ IT } & \multirow[b]{2}{*}{$\mathrm{R}_{\mathrm{s}}{ }^{*}$} & \multirow{2}{*}{$\begin{array}{c}\text { Slagging } \\
\text { classification of } \\
\text { samples }\end{array}$} \\
\hline & & $\left({ }^{\circ} \mathrm{C}\right)$ & $\left({ }^{\circ} \mathrm{F}\right)$ & $\left({ }^{\circ} \mathrm{C}\right)$ & $\left({ }^{\circ} \mathrm{F}\right)$ & & \\
\hline PP & $\begin{array}{l}25: 75 \\
50: 50\end{array}$ & $\begin{array}{l}1,284 \\
1,340\end{array}$ & $\begin{array}{l}2,343 \\
2,444\end{array}$ & $\begin{array}{l}1,208 \\
1,274\end{array}$ & $\begin{array}{l}2,206 \\
2,325\end{array}$ & $\begin{array}{l}2,233 \\
2,348\end{array}$ & $\begin{array}{c}\text { High } \\
\text { Medium }\end{array}$ \\
\hline
\end{tabular}

Table 18. Slagging tendency coal ash type of bituminous

\begin{tabular}{ccccccc}
\hline Sample codes & Ratio & $\begin{array}{c}\mathrm{Base} \\
\mathrm{Fe}_{2} \mathrm{O}_{3}+\mathrm{CaO}+ \\
\mathrm{MgO}+\mathrm{Na}_{2} \mathrm{O}+\mathrm{K}_{2} \mathrm{O} \\
(\%)\end{array}$ & $\begin{array}{c}\text { Acid } \\
\mathrm{SiO}_{2}+\mathrm{Al}_{2} \mathrm{O}_{3} \\
+\mathrm{TiO}_{2}(\%)\end{array}$ & Sulfur & $\begin{array}{c}\text { Slagging } \\
\text { index }\end{array}$ & $\begin{array}{c}\text { Slagging } \\
\text { classification }\end{array}$ \\
\hline PP & $75: 25$ & 19.25 & 75.98 & 0.28 & 0,07 & Low \\
\hline \multirow{2}{*}{$\mathrm{PS}$} & $25: 75$ & 22.28 & 66.96 & 0.40 & 0.13 & Low \\
& $50: 50$ & 18.82 & 73.58 & 0.36 & 0.09 & Low \\
& $75: 25$ & 16.94 & 76.7 & 0.33 & 0.07 & Low \\
\hline \multirow{3}{*}{$\mathrm{PM}$} & $25: 75$ & 34.79 & 56.38 & 0.28 & 0.17 & Low \\
& $50: 50$ & 25.6 & 67.67 & 0.28 & 0.11 & Low \\
& $75: 25$ & 19.96 & 73.76 & 0.29 & 0.08 & Low \\
\hline
\end{tabular}

Table 19. Fouling index bituminous ash type of blended coal

\begin{tabular}{|c|c|c|c|c|c|c|c|c|c|c|}
\hline \multirow{2}{*}{ Sample code } & \multirow{2}{*}{ Ratio } & \multicolumn{5}{|c|}{ Base compound (\%) } & \multicolumn{3}{|c|}{ Acid compound (\%) } & \multirow{2}{*}{$\begin{array}{c}\text { Fouling } \\
\text { index } \\
R_{f}\end{array}$} \\
\hline & & $\mathrm{CaO}$ & $\mathrm{MgO}$ & $\mathrm{Fe}_{2} \mathrm{O}_{3}$ & $\mathrm{Na}_{2} \mathrm{O}$ & $\mathrm{K}_{2} \mathrm{O}$ & $\mathrm{Al}_{2} \mathrm{O}_{3}$ & $\mathrm{SiO}_{2}$ & $\mathrm{TiO}_{2}$ & \\
\hline PP & $75: 25$ & 6.31 & 1.53 & 10.88 & 0.30 & 0.23 & 33.40 & 41.20 & 1.38 & 0.13 \\
\hline \multirow{3}{*}{ PS } & $25: 75$ & 7.46 & 2.27 & 11.67 & 0.57 & 0.31 & 27.76 & 38.00 & 1.20 & 0.29 \\
\hline & $50: 50$ & 5.22 & 1.63 & 11.15 & 0.55 & 0.27 & 30.0 & 41.40 & 1.28 & 0.21 \\
\hline & $75: 25$ & 4.35 & 1.21 & 10.97 & 0.19 & 0.22 & 32.30 & 43.00 & 1.41 & 0.15 \\
\hline \multirow{3}{*}{ PM } & $25: 75$ & 10.63 & 4.52 & 17.94 & 1.36 & 0.34 & 16.98 & 38.50 & 0.90 & 1.05 \\
\hline & $50: 50$ & 7.28 & 2.67 & 14.70 & 0.70 & 0.25 & 25.20 & 41.40 & 1.07 & 0.36 \\
\hline & $75: 25$ & 5.04 & 1.65 & 12.42 & 0.62 & 0.23 & 29.33 & 43.10 & 1.33 & 0.23 \\
\hline
\end{tabular}

Table 20. Fouling index lignite of blended coal

\begin{tabular}{ccccccc}
\hline Samplecodes & Ratio & $\mathrm{CaO}(\%)$ & $\mathrm{MgO}(\%)$ & $\begin{array}{c}\mathrm{Fe}_{2} \mathrm{O}_{3} \\
(\%)\end{array}$ & $\begin{array}{c}\text { Total amount } \\
(\%)\end{array}$ & Classification \\
\hline PP & $25: 75$ & 15.84 & 3.29 & 10.18 & 29.31 & Low-medium \\
& $50: 50$ & 10.20 & 2.23 & 10.79 & 23.22 & Low-medium \\
\hline
\end{tabular}




\section{CONCLUSIONS}

Coal blending is an effective way to organize and control coal ash fusibility in terms of meeting the requirements of coal during combustion. The results indicate-that Pendopo coal ash was classified as bituminous ash, while the ash type of Palangkaraya, Samarinda and Muara Enim coals were classified as the lignite. Slagging and fouling index calculation showed that the best composition happened in the blended of Pendopo and Palangkaraya coals with the ratio of $25: 75$ and $50: 50$.

\section{ACKNOWLEDGEMENT}

The author would like to acknowledge the R\&D Centre for Mineral and Coal Technology that has provided funding and facilities to conduct this research. Thanks also to all members of PLTD Gasification team for supporting experiment data.

\section{REFERENCES}

Amaliyah, N. and Fachry, M. (2011) 'Analisis komposisi batubara mutu rendah terhadap pembentukan plagging dan fouling pada boiler', in Prosiding 2011: Hasil Penelitian Fakultas Teknik, pp. TM10-1-10.

ASTM D1857/D1857M-17 (2017) 'Standard test method for fusibility of coal and coke ash', in Annual Book of ASTM Standards. 05.06. ASTM International, pp. 502-505.

ASTM D2013-12 (2017) 'Standard practice for preparing coal samples for analysis', in Annual Book of ASTM Standard. 05.06. ASTM International, pp. 506-517.

ASTM D388-15 (2017) 'Standard classification of coals by rank', in Annual Book of ASTM Standards. 05.06. ASTM International, pp. $460-466$.

Gupta, S., Dubikova, M., French, D. and Sahajwalla, V. (2007) 'Characterization of the origin and distribution of the minerals and phases in metallurgical cokes', Energy \& Fuels, 21(1), pp. 303313. doi: 10.1021/ef060437d.

Li, J., Zhu, M., Zhang, Z., Zhang, K., Shen, G. and Zhang, D. (2016) 'The mineralogy, morphology and sintering characteristics of ash deposits on a probe at different temperatures during combustion of blends of Zhundong lignite and a bituminous coal in a drop tube furnace', Fuel Processing Technology, 149, pp. 176-186. doi: 10.1016/j.fuproc.2016.04.021.

Lolja, S. A., Haxhi, H., Dhimitri, R., Drushku, S. and Malja, A. (2002) 'Correlation between ash fusion temperatures and chemical composition in Albanian coal ashes ${ }^{\prime}{ }^{\prime}$, Fuel, 81(17), pp. 2257-2261. doi: 10.1016/S0016-2361(02)00194-1.

Lu, X. and Wang, T. (2015) 'Simulation of ash deposition behavior in an entrained flow coal gasifier', International Journal of Clean Coal and Energy, 04(02), pp. 4359. doi: 10.4236/ijcce.2015.42005.

Pintana, P., Tippayawong, N., Nuntaphun, A. and Thongchiew, P. (2014) 'Characterization of slag from combustion of pulverized lignite with high calcium content in utility boiler', Energy Exploration \& Exploitation, 32(3), pp. 471-482. doi: 10.1260/0144-5987.32.3.471

Qi, X., Song, G., Song, W. and Yang, S. (2017) 'Effect of bed materials on slagging and fouling during Zhundong coal gasification', Energy Exploration \& Exploitation, 35(5), pp. 558-578. doi: $10.1177 / 0144598717700082$

Russell, N. V., Wigley, F. and Williamson, J. (2002) 'The roles of lime and iron oxide on the formation of ash and deposits in PF combustion', Fuel, 81(5), pp. 673-681. doi: 10.1016/S0016-2361(01)00154-5.

Sharma, A., Saikia, A., Khare, P., Dutta, D. K. and Baruah, B. P. (2014) 'The chemical composition of tertiary Indian coal ash and its combustion behaviour - a statistical approach: Part 2', Journal of Earth System Science, 123(6), pp. 14391449. doi: 10.1007/s12040-014-0475-3.

Shen, M., Qiu, K., Zhang, L., Huang, Z., Wang, Z. and Liu, J. (2015) 'Influence of coal blending on ash fusibility in reducing atmosphere', Energies, 8(6), pp. 47354754. doi: 10.3390/en8064735.

Song, W. J., Tang, L. H., Zhu, X. D., Wu, Y. Q., Zhu, Z. B. and Koyama, S. (2010) 'Effect of coal ash composition on ash fusion temperatures †', Energy \& Fuels, 24(1), pp. 182-189. doi: 10.1021/ef900537m.

Vijay, J. J. C., Lawrence, A. and Arthanareeswaran, G. (2017) 'Analytical 
INDONESIAN MINING JOURNAL Vol. 22, No. 1, April $2019: 49$ - 60

tool for analysing slagging characteristic of high ash coals in utility boilers', International Journal of Mechanical Engineering and Technology, 8(3), pp. 185-196. Available at:

http://www.iaeme.com/MasterAdmin/Jou rnal_uploads/IJMET/VOLUME_8_ISSUE _3/IJMET_08_03_021.pdf.
Wang, P. and Massoudi, M. (2013) 'Slag behavior in gasifiers. Part I: Influence of coal properties and gasification conditions', Energies, 6(2), pp. 784-806. doi: 10.3390/en6020784. 